Jurnal Indonesia Sosial Teknologi: p-ISSN: 2723 - 6609

e-ISSN : 2548-1398

Vol. 1, No. 3 Oktober 2020

\title{
RANCANG BANGUN SISTEM INFORMASI SURAT MASUK DAN SURAT KELUAR BERBASIS WEB MENGGUNAKAN METODE WATERFALL
}

\author{
Riswandi Ishak, Setiaji, Fajar Akbar, dan Mahmud Safudin \\ Universitas Bina Sarana Informatika, STMIK Nusa Mandiri \\ Email : riswandi.rik@bsi.ac.id; setiaji.sej@bsi.ac.id; fajar.fkb@nusamandiri.ac.id; dan \\ mahmud.mud@bsi.ac.id
}

\begin{abstract}
Abstrac
Correspondence is the most important tool in the administrative section, one of its forms is the activity of managing incoming and outgoing mail. The management of incoming and outgoing letters at SMP Negeri 207 Jakarta still uses the conventional method, which means storing letters and data in the form of stacked sheets of paper. It can cause loss or damage to the paper and the search for letters can take a long time. In addition, letters are recorded in the agenda book using handwriting which can cause repetition of letter numbers. To solve this problem, an information system is needed that can properly manage incoming and outgoing mail and write mail reports. In the incoming and outgoing mail system at SMP Negeri 207 Jakarta which will be developed on a website basis by making program code using a CI-based framework (Code Igniter). The method used is SDLC (System Development Life Cycle) with a waterfall model. This method is expected to develop a system in an orderly and clear manner. The results of this research are the design of an information system for incoming and outgoing mail at SMP Negeri 207 Jakarta as a mail management system, mail search and mail storage media that is more structured and provides convenience.
\end{abstract}

Keyword : Information System, Management of Incoming and Outgoing Mail, Waterfall

\begin{abstract}
Abstrak
Surat menyurat merupakan sarana terpenting dalam bagian keadministrasian salah satu bentuknya adalah kegiatan pengurusan surat masuk dan surat keluar. Pengelolaan surat masuk dan surat keluar pada SMP Negeri 207 Jakarta masih menggunakan cara konvensional yang artinya menyimpan surat dan data-data dalam bentuk selembaran kertas yang disusun bertumpuk. Hal itu dapat menimbulkan kehilangan atau kerusakan pada kertas dan dalam pencarian surat memakan waktu yang lama. Selain itu surat dicatat dalam buku agenda menggunakan tulisan tangan yang dapat menimbulkan pengulangan nomor surat. Untuk mengatasi permasalahan tersebut, dibutuhkan sebuah sistem informasi yang dapat mengelola surat masuk, surat keluar hingga pembuatan laporan surat dengan baik. Pada sistem surat masuk dan surat keluar pada SMP Negeri 207 Jakarta yang akan dikembangkan berbasis website dengan pembuatan kode program menggunakan framework berbasis CI (Code Igniter). Metode yang digunakan adalah SDLC (System Development Life Cycle) dengan model air terjun (waterfall) dengan metode ini diharapkan dapat mengembangkan sistem dengan terurut dan jelas. Hasil dari penelitian ini adalah rancang bangun sistem informasi surat masuk dan surat keluar pada SMP Negeri 207 Jakarta sebagai sistem pengelolaan surat, pencarian surat dan media penyimpanan surat yang lebih terstruktur dan memberi kemudahan.
\end{abstract}


Kata kunci : Sistem Informasi, Pengelolaan Surat Masuk dan Keluar, Waterfall

\section{Pendahuluan}

Pesatnya perkembangan teknologi pada era globalisasi saat ini telah memberikan dampak pada semua aspek kehidupan. Hal ini tidak dapat dipungkiri dikarenakan kemajuan teknologi yang sangat cepat. Suatu sistem informasi dapat dihasilkan oleh Teknologi Informasi,dimana pemanfaatanya digunakan oleh pengguna diberbagai intansi, perusahaan, atau lembaga baik swasta maupun pemerintahan.

Surat menyurat merupakan sarana terpenting dalam bagian keadministrasian terutama pada instansi sekolah. Salah satu bentuk surat menyurat adalah dengan melakukan kegiatan pengurusan surat baik surat masuk dan surat keluar sesuai prosedurnya (Desti \& Nugroho, 2019). Pengelolaan surat masuk dan surat keluar pada SMP Negeri 207 Jakarta selama ini masih menggunakan cara konvensional yang artinya menyimpan surat kertas dalam lemari penyimpanan.

Bentuk penyimpanan dengan menumpuk surat akan menimbulkan kehilangan atau kerusakan pada kertas. Dan untuk pencarian surat masuk dan surat keluar tidak dapat berjalan secara efisien karena memakan banyak waktu dan tenaga (Suryadi \& Zulaikhah, 2019). Selain itu surat masuk dan surat keluar dicatat dalam buku agenda dengan menggunakan tulisan tangan sehingga bisa menimbulkan pengulangan nomor surat.(Sonita \& Sari, 2018).

Dengan Pengelolaan surat masuk dan surat keluar pada SMP Negeri 207 Jakarta yang menggunakan cara konvensional dapat memungkinkan data hilang, rusak dan menyulitkan dalam melakukan pencarian data jika suatu waktu diperlukan. Dibutuhkan suatu sistem informasi yang dapat membantu dalam menyelesaikan permasalahan tersebut. Sistem informasi ini bertujuan untuk meningkatkan efisiensi, ketepatan dan keamanan dokumen suratnya.

Menurut Jogianto dalam Hamim Tohiri dalam (Saryoko, 2017) mengatakan bahwa, "sistem adalah kumpulan elemen - elemen yang berinteraksi untuk mencapai tujuan tertentu". Sedangkan menurut Tata Sutabri dalam (Supriyatna, 2015) mengatakan bahwa, "sistem adalah suatu kumpulan atau himpunan dari unsur unsur, komponen atau variable yang terorganisir, saling terintegrasi, saling berinteraksi, saling tergantung satu sama lain dan terpadu". Menurut Sutabri dalam (Handayani et al., 2018) menjelaskan bahwa, "Informasi adalah data yang diklasifikasikan atau diolah atau diinterpretasikan untuk digunakan dalam proses pengambilan keputusan"

Menurut Stair dan Reynolds dalam (Wiguna, 2017) mengatakan bahwa, "Sistem informasi (SI) adalah seperangkat komponen yang saling terkait dalam mengumpulkan, memproses, menyimpan, serta menyebarkan data dan informasi". Menurut Jogiyanto dalam (Supriyatna, 2015), "sistem informasi adalah suatu sistem di dalam suatu organisasi yang mempertemukan kebutuhan pengolahan transaksi harian, mendukung operasi, bersifat manajerial dan kegiatan strategi dari suatu organisasi dan menyediakan pihak luar tertentu dengan laporan - laporan yang 
diperlukan" sedangkan menurut (Mulyani \& Purnama, 2013) Sistem informasi adalah kumpulan/group dari bagian/komponen apapun baik pisik maupun non pisik yang saling berhubungan satu sama lain dan bekerjasama secara harmonis untuk mencapai satu tujuan tertentu.

Perancangan sistem Informasi surat masuk dan surat keluar berbasis web ini diharapkan mampu membantu dalam pengelolaan surat dan dokumen,sehingga memudahkan untuk mendapatkan informasi serta meningkatkan efektifitas kinerja karyawan.

\section{Metode Penelitian}

metode yang digunakan untuk merancang bangun sistem informasi informasi surat masuk dan surat keluar adalah metode pengembangan perangkat lunak yaitu model waterfall, Model waterfall menyediakan pendekatan alur hidup perangkat lunak secara sekuensial atau terurut dimulai dari analisis kebutuhan software, desain, pengodean, pengujian, dan tahap pendukung (support) (Hidayat et al., 2017).

Menurut (Rosa, 2016) mengemukakan bahwa "Model SDLC waterfall disebut juga dengan model sekuensial linier (sequential linear) atau alur hidup klasik (classic life cycle)". Berikut tahapan pengembangan perangkat lunak untuk sistem informasi surat masuk dan surat keluar, sebagai berikut:

1. Analisis

Pada tahap ini penulis mempelajari sistem surat masuk dan surat keluar yang sedang berjalan serta mengevaluasi permasalahan yang ada seperti : banyaknya tumpukan kertas surat yang tidak tersusun rapi dan sulitnya pencarian surat jika suatu waktu diperlukan. Sehingga sistem surat masuk dan surat keluar pada SMP Negeri 207 Jakarta membutuhkan sistem yang terkomputerisasi untuk mempermudah pegawai tata usaha dalam pengelolaan surat masuk dan surat keluar

2. Desain

Dalam perancangan sistem ini penulis menggunakan tools untuk mendesain sistem agar lebih terstruktur seperti: ERD (Entity Relationship Diagram), LRS (Logical Record Structure) dan UML (Unified Modelling Language). Sistem ini dirancang dengan software StarUML dari mulai membuat activity diagram, use case diagram, class diagram dan sequence diagram

3. Pengkodean

Pada tahap ini perangkat lunak dijalankan sebagai serangkaian program atau unit program melalui pembuatan database menggunakan aplikasi MySQL. Dan pembuatan kode program menggunakan framework berbasis CI (Code Igniter) yang dapat diakses melalui browser dan program pendukung XAMPP yang terintegrasi dengan MySQL dan Apache

4. Pengujian

Pengujian dilakukan untuk memastikan bahwa setiap bagian sudah sesuai padaa rangkaian proses yang telah dibuat pada tahap sebelumnya. Pengujian 
dilakukan dengan metode black box testing yaitu menguji bahwa setiap unit telah memenuhi fungsi dan logika secara benar sesuai kebutuhan pengguna.

5. Pendukung (Support)

Pendukung merupakan suatu tindakan dalam pemeliharaan dan pengubahan dalam pengembangan perangkat lunak yang telah dibuat dan tidak terdeteksi pada tahap pengujian. Hal ini dapat menyebabkan penyesuaian sistem dengan lingkungan yang baru untuk mengetahui apakah sistem yang telah dibuat ini memiliki kekurangan atau tidak

\section{Hasil Penelitian dan Pembahasan}

1. Kebutuhan pengguna

Dalam program surat masuk dan surat keluar terdapat dua pengguna yang dapat saling berinteraksi dalam lingkungan sistem yaitu: Admin dan Operator. Kedua pengguna tersebut memiliki karakteristik interaksi dengan sistem yang berbeda-beda.

2. Kebutuhan Sistem

Pengguna harus melakukan login terlebih dahulu dengan memasukan username dan password masing-masing. Sistem memverifikasi data pengguna sesuai username dan password yang benar. Pengguna harus melakukan logout apabila sudah selesai. Sistem memiliki button untuk tambah, ubah, hapus, simpan dan batal pada halaman surat masuk, surat keluar, instansi, konfigurasi aplikasi dan manajemen user. Sistem menyimpan data surat masuk, surat keluar, disposisi, instansi, konfigurasi aplikasi, dan user. Sistem kalkulasi jumlah seluruh surat untuk rekapitulasi surat Sistem memiliki button cetak laporan surat sesuai tanggal yang diinput pengguna.

\section{Diagram use case}

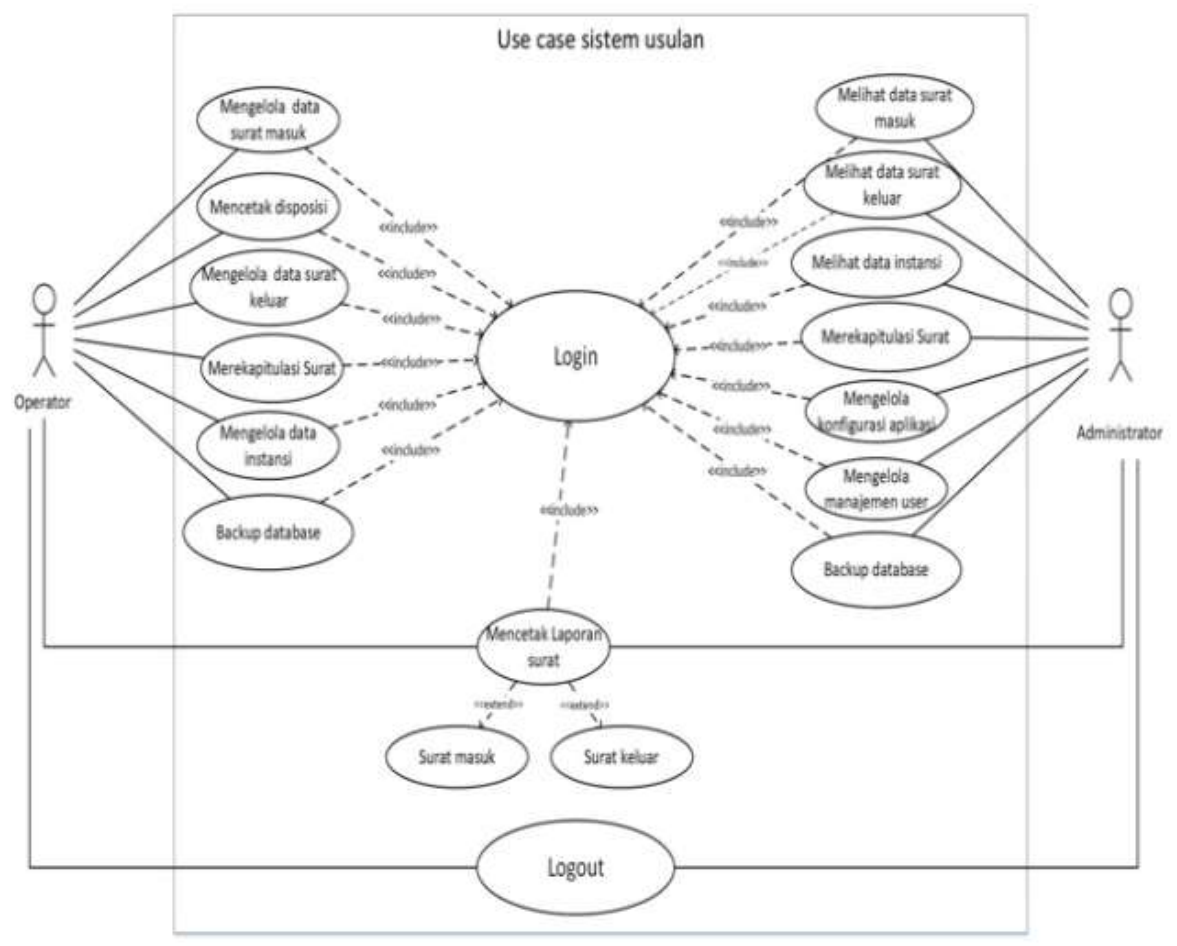

Sumber : (Penelitian, 2020) 
Riswandi Ishak, Setiaji, Fajar Akbar dan Mahmud Safudin

\section{Rancang Diagram Surat Masuk}

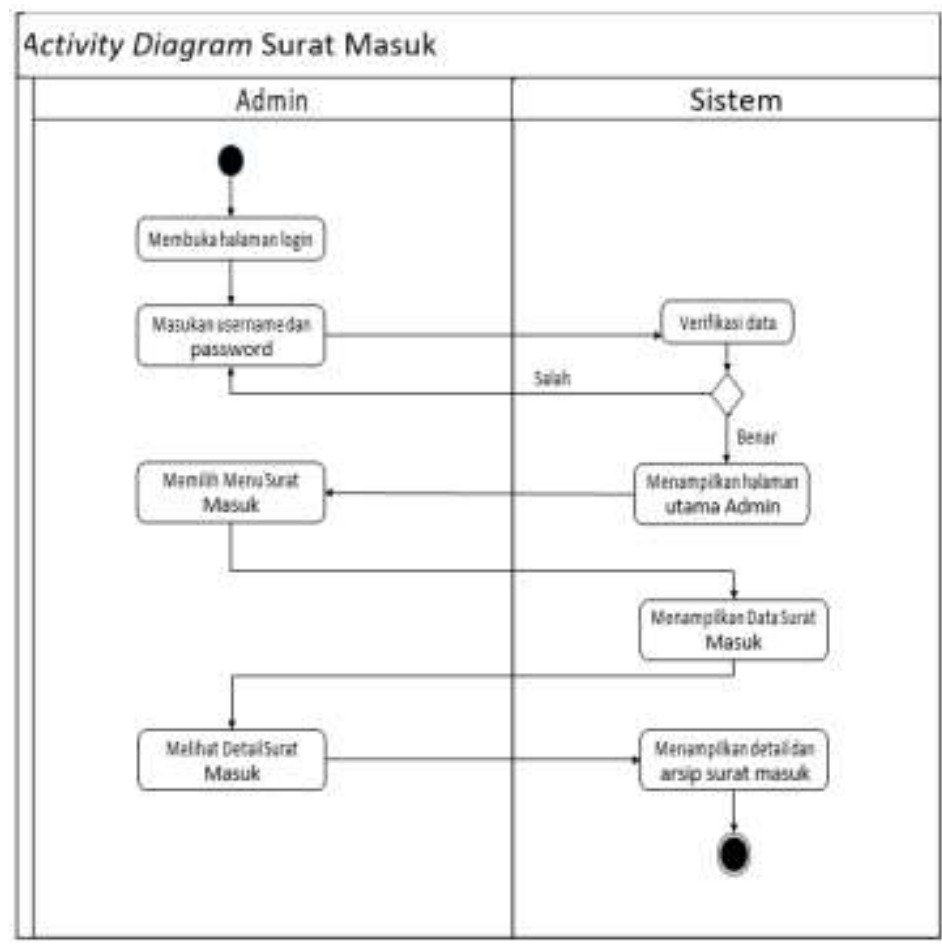

Sumber : (Penelitian, 2020)

\section{Rancang Diagram Surat Keluar}

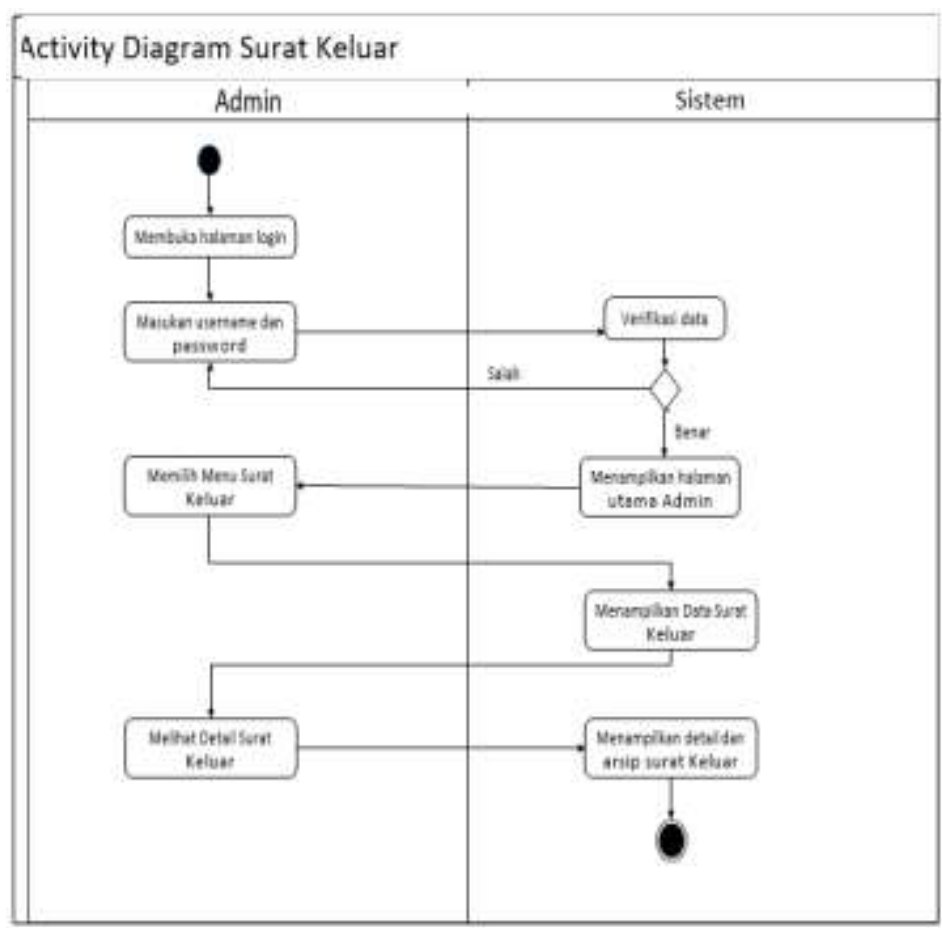

Sumber : (Penelitian, 2020) 


\section{Rancangan Prototype}

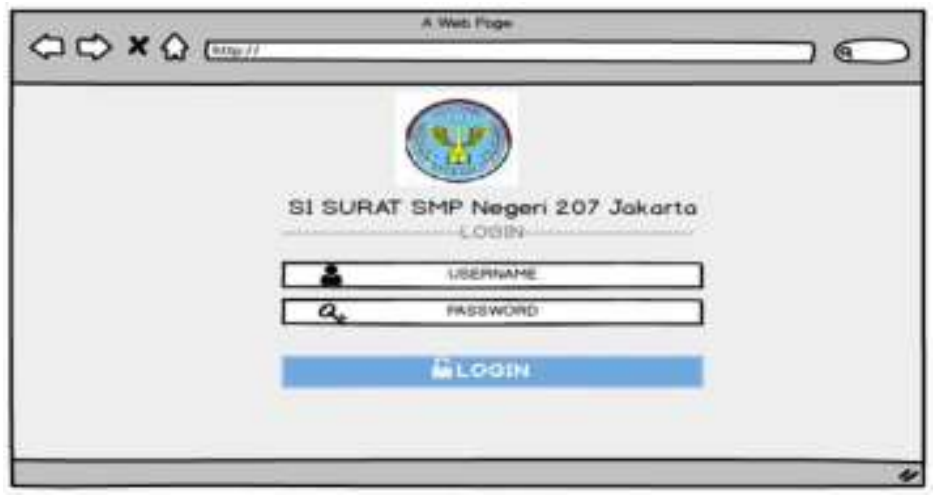

Halaman Login

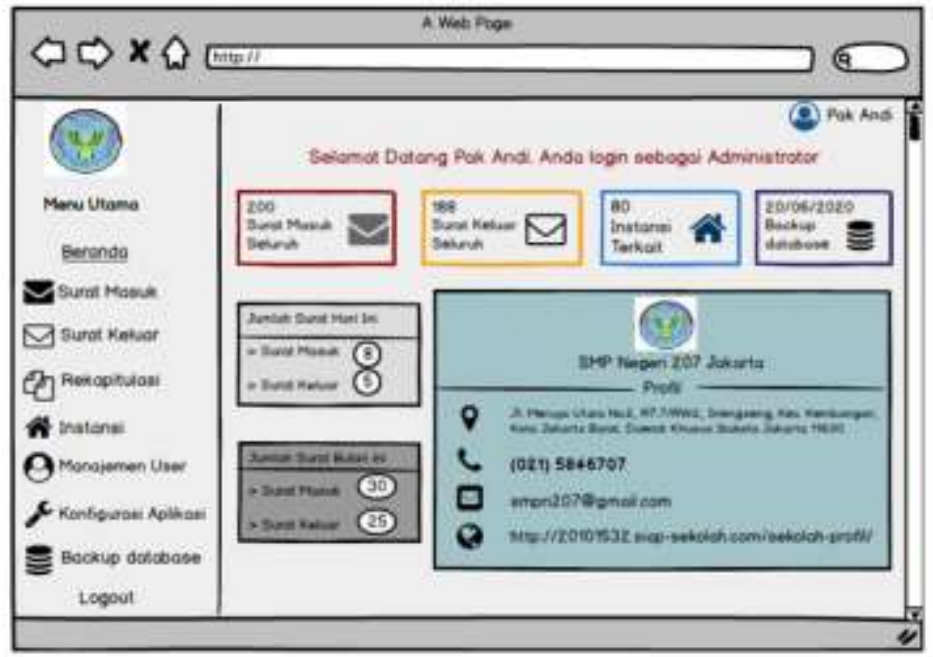

Halaman Utama Login

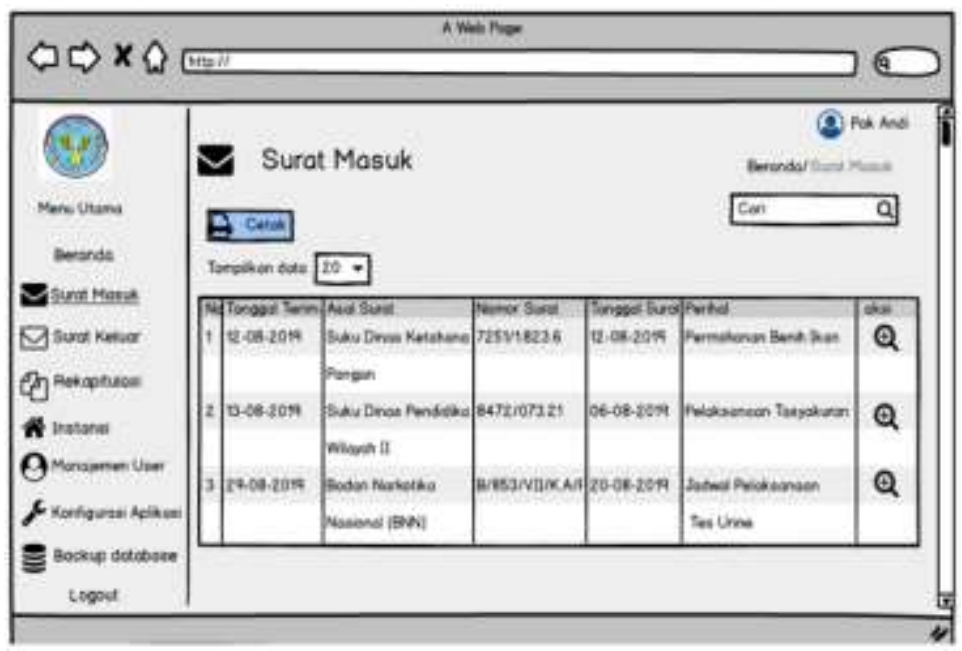

Halaman Admin Surat Masuk 
Riswandi Ishak, Setiaji, Fajar Akbar dan Mahmud Safudin

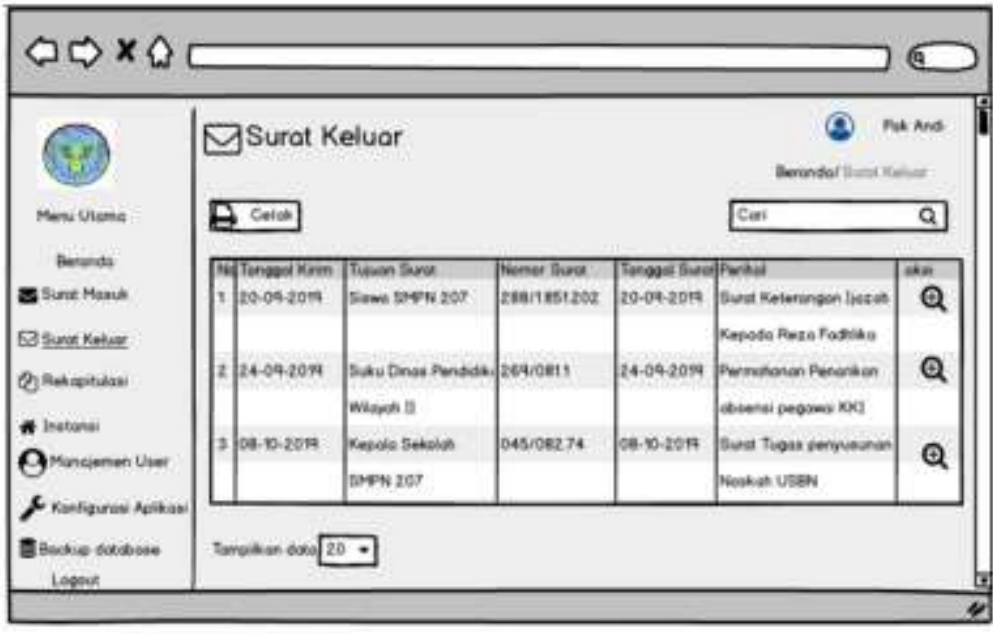

Halaman Admin Surat Keluar

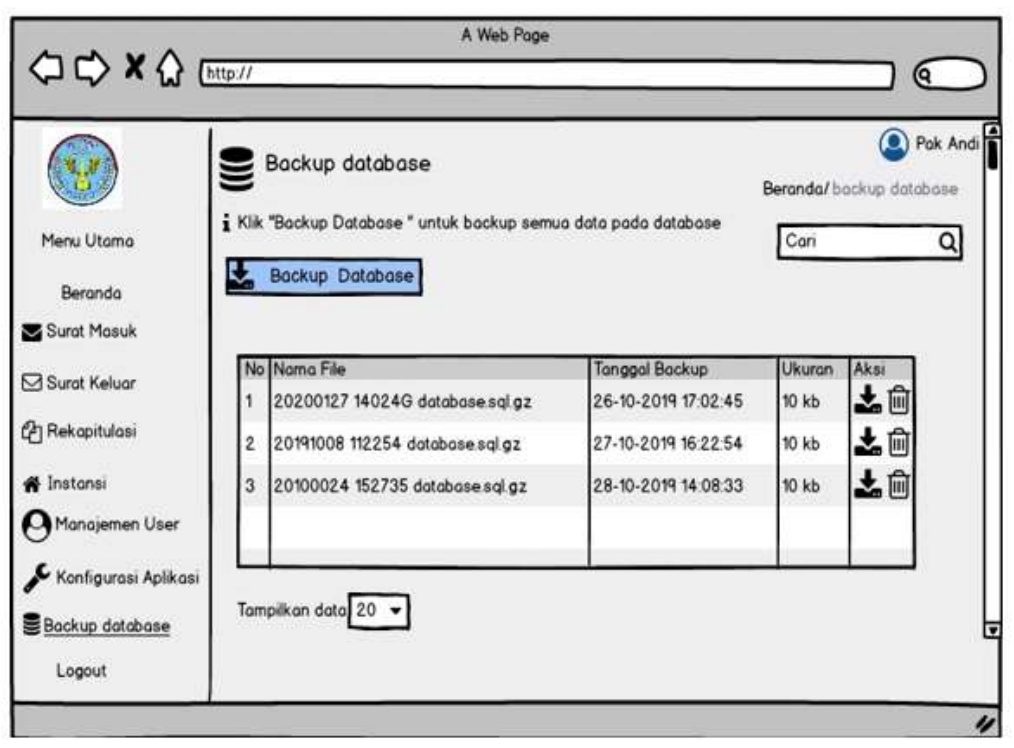

Halaman Admin Backup Database

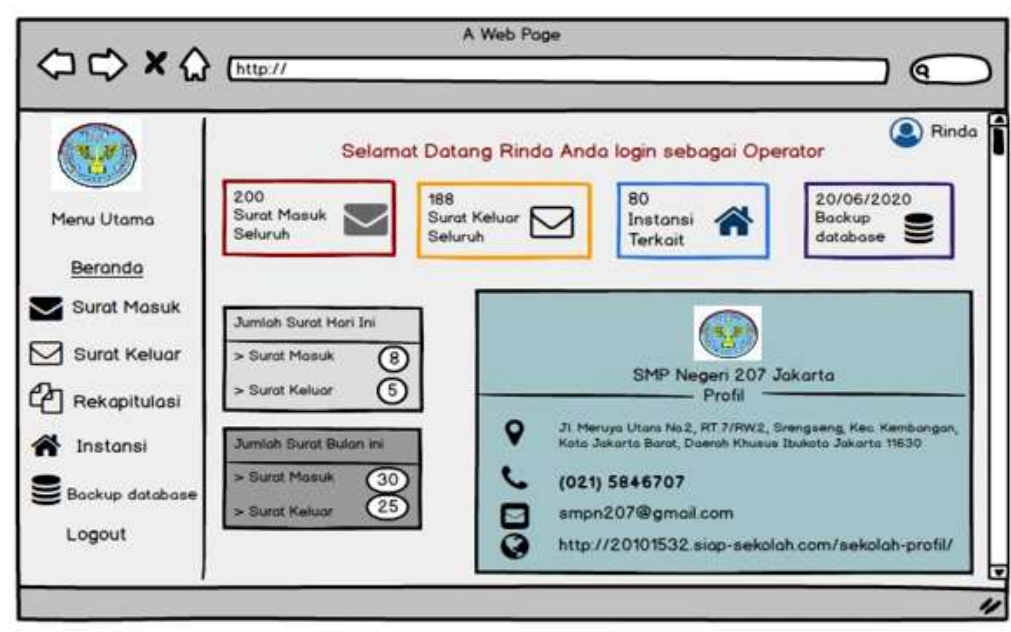

Halaman Utama Operator 
Riswandi Ishak, Setiaji, Fajar Akbar

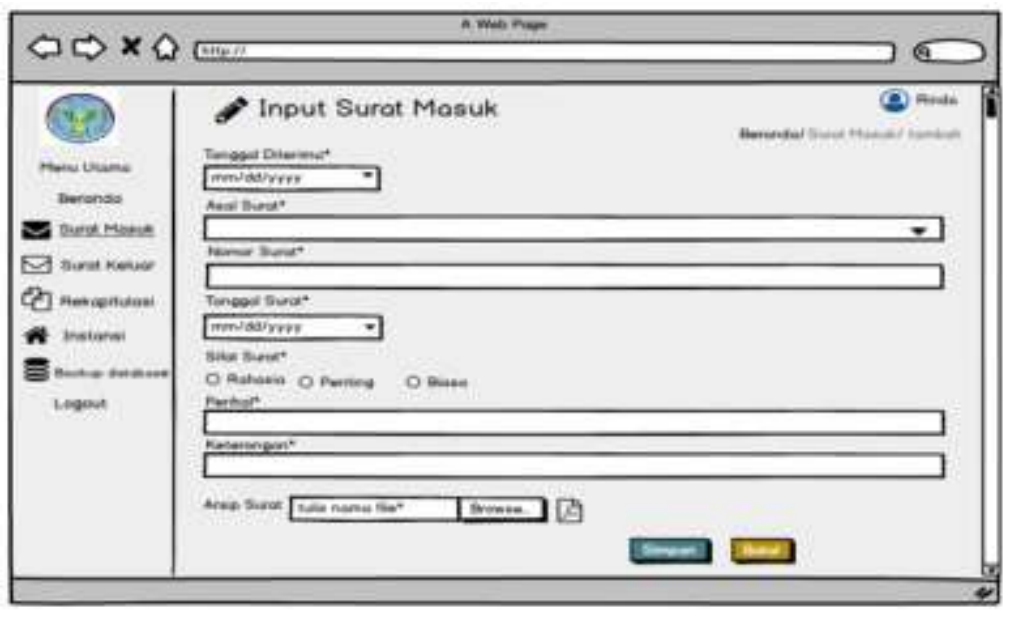

Halaman Input Surat Masuk

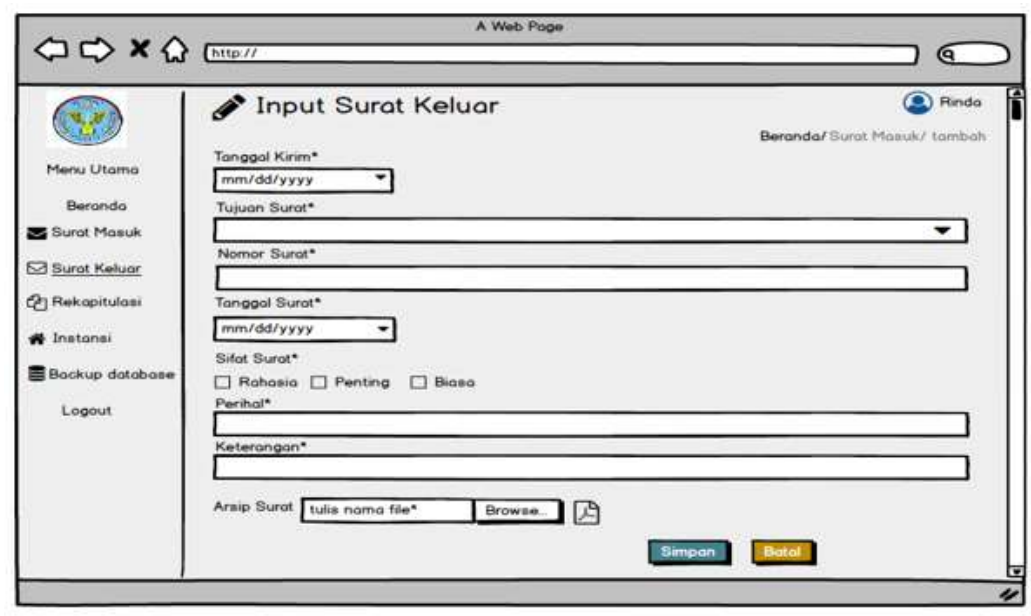

Halaman Input Surat Keluar 
Riswandi Ishak, Setiaji, Fajar Akbar dan Mahmud Safudin

ERD (Entity Relationship Diagram)

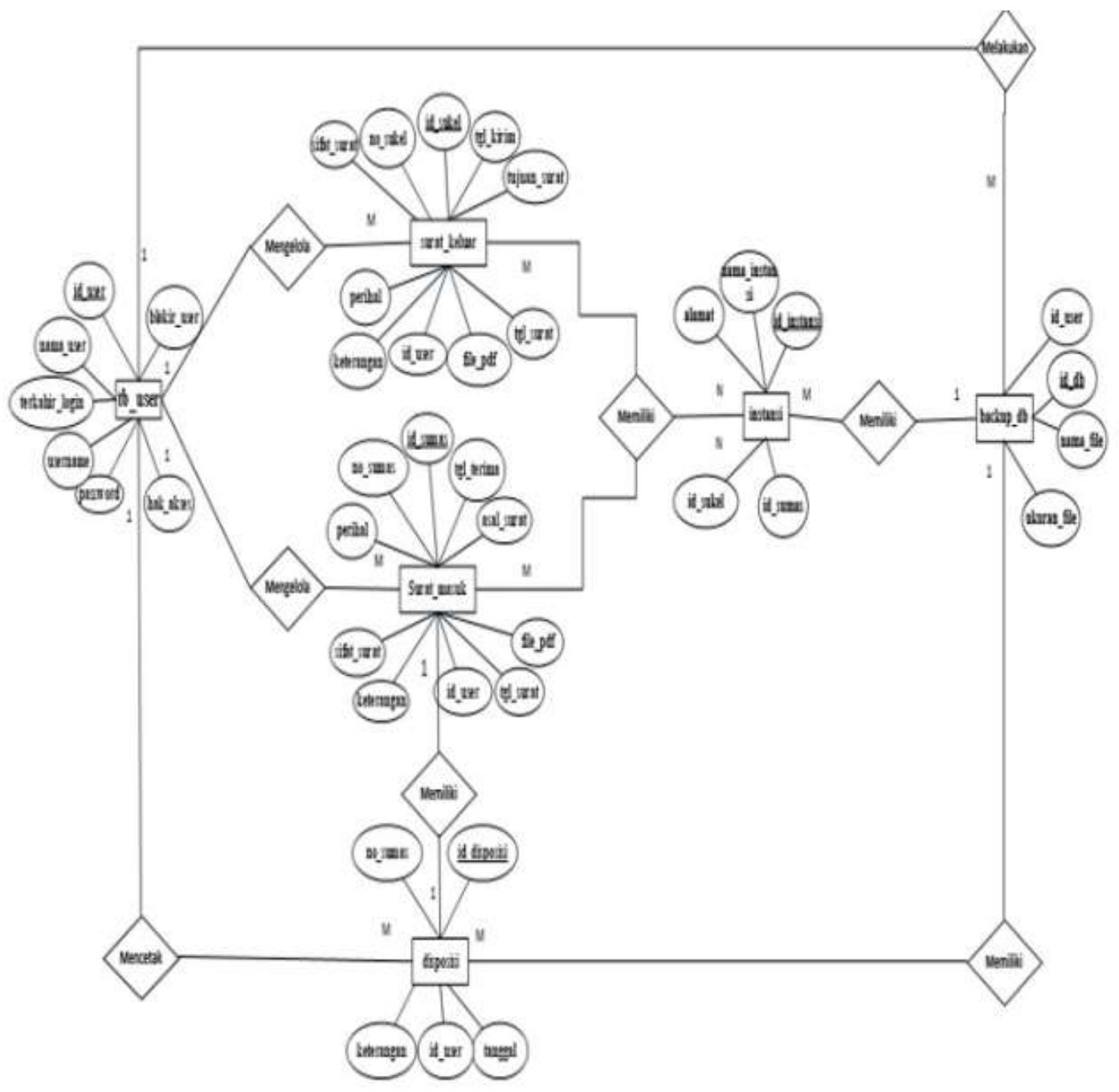


Riswandi Ishak, Setiaji, Fajar Akbar

LRS (Logical Structure Record)

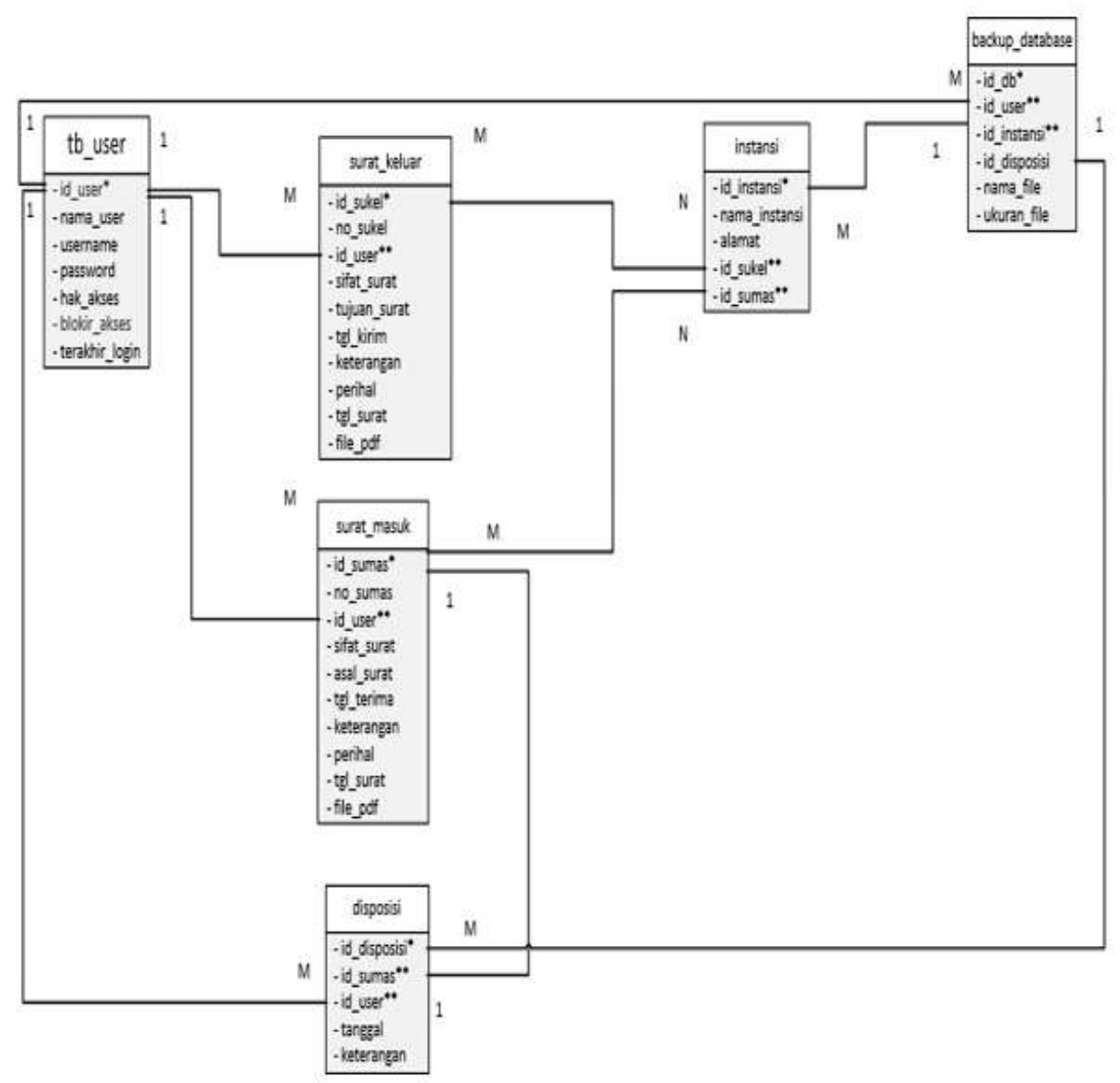


Riswandi Ishak, Setiaji, Fajar Akbar dan Mahmud Safudin

\section{Kesimpulan}

Berdasarkan uraian yang telah dijelaskan sebelumnya, dengan mengubah sistem manual menjadi sistem terkomputerisasi diharapkan dapat mengatasi permasalahan surat masuk dan surat keluar pada SMP Negeri 207 Jakarta. Seperti Sistem informasi surat masuk dan surat keluar dapat memberikan kemudahan bagi pegawai tata usaha dalam mengelola surat. Misalnya dahulu data surat dicatat secara tertulis dalam buku agenda, sekarang data surat sudah bisa diinput secara terkomputerisasi.

Sistem informasi surat masuk dan surat keluar dapat mengkalkulasi jumlah seluruh surat, sehingga dapat membantu pegawai tata usaha dalam merekapitulasi dan pembuatan laporan surat dengan cepat. 


\section{Bibliografi}

Desti, A. R., \& Nugroho, Y. A. (2019). Perancangan Sistem Informasi Surat Masuk Dan Surat Keluar Menggunakan Delphi 7 Pada Dinas Perumahan, Permukiman Dan Pemakaman Kabupaten Tangerang. Insan Pembangunan Sistem Informasi Dan Komputer (IPSIKOM), 7(2).

Handayani, V. R., Wijianto, R., Anggoro, A., \& Informatika, M. (2018). Sistem Informasi Pendaftaran Seleksi Kerja Berbasis Web Pada Bkk (Bursa Kerja Khusus) Tunas Insan Karya Smk Negeri 2 Banyumas. Jurnal Evolusi, 6(1), 76-84.

Hidayat, R., Marlina, S., \& Utami, L. D. (2017). Perancangan Sistem Informasi Penjualan Barang Handmade Berbasis Website Dengan Metode Waterfall. Simnasiptek 2017, 1(1), 175-183.

Mulyani, W., \& Purnama, B. E. (2013). Pembangunan Sistem Informasi Data Balita Pada Posyandu Desa Ploso Kecamatan Punung Kabupaten Pacitan. Speed-Sentra Penelitian Engineering Dan Edukasi, 7(2).

Rosa, A. S. (2016). Rekayasa perangkat lunak terstruktur dan berorientasi objek.

Saryoko, A. (2017). Sistem Informasi Tiket Bioskop Pada Buaran Teater Di Jakarta Timur Berbasis Web. Jurnal Pilar Nusa Mandiri, 13(1), 98-102.

Sonita, A., \& Sari, M. (2018). Implementasi Algoritma Sequential Searching Untuk Pencarian Nomor Surat Pada Sistem Arsip Elektronik. Pseudocode, 5(1), 1-9.

Supriyatna, A. (2015). Analisis Dan Evaluasi Kepuasan Pengguna Sistem Informasi Perpustakaan Dengan Menggunakan Pieces Framework. Jurnal Pilar Nusa Mandiri, 11(1), 43-52.

Suryadi, A., \& Zulaikhah, Y. S. (2019). Rancang Bangun Sistem Pengelolaan Arsip Surat Berbasis Web Menggunakan Metode Waterfall. Jurnal Khatulistiwa Informatika, 7(1).

Wiguna, W. (2017). Adopsi Sistem Informasi Akademik Perguruan Tinggi BSI Bandung Berbasis TAM. Jurnal Informatika, 4(2). 